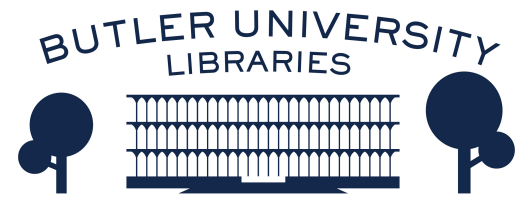

Journal of Hindu-Christian Studies

\title{
Devotion and Discipline: Christian Yoga and the Yoga of T. Krishnamacharya
}

Stephanie Corigliano

Humboldt State University

Follow this and additional works at: https://digitalcommons.butler.edu/jhcs

Part of the Christianity Commons, and the Religious Thought, Theology and Philosophy of Religion Commons

\section{Recommended Citation}

Corigliano, Stephanie (2017) "Devotion and Discipline: Christian Yoga and the Yoga of T. Krishnamacharya," Journal of Hindu-Christian Studies: Vol. 30, Article 4.

Available at: https://doi.org/10.7825/2164-6279.1656

The Journal of Hindu-Christian Studies is a publication of the Society for Hindu-Christian Studies. The digital version is made available by Digital Commons @ Butler University. For questions about the Journal or the Society, please contact cbauman@butler.edu. For more information about Digital Commons @ Butler University, please contact digitalscholarship@butler.edu. 


\section{Devotion and Discipline: Christian Yoga and the Yoga of T. Krishnamacharya}

\section{Stephanie Corigliano Humboldt State University}

SA tu dïrgha-kāla-nairantarya-satkārāsevito dṛḍhabhūṃih, Yogasūtra 1.14 states, "Practice becomes firmly established when it has been cultivated uninterruptedly and with devotion over a prolonged period of time."

As a student of the late Pattabhi Jois, I heard this sūtra countless times during Jois's afternoon conferences with his students. In the context of practice in Mysore with Jois, I understood the concept of discipline. However, the concept of devotion, satkārāa, was more ambiguous. Questions about God and devotion were usually met with a simple, "God is one."

Jois was one of a few proponents of Yoga in the modern era to have learned from Tirumalai Krishnamacharya. As guru, or teacher, to BKS Iyengar, Pattabhi Jois, and TKV Desikachar, Krishnamacharya is recognized as the founder of many of the forms of Yoga that are popular today. For example, American "Power Yoga," many forms of "Yoga therapy," and all types of "Vinyasa/Flow Yoga" are derived from the methods originally taught by Krishnamacharya.

Interestingly, the importance of a theistic/devotional stance is prominent in the philosophical work and prose of Krishnamacharya, yet it is set forth as part of a non-sectarian perspective. For example, one verse of his Yogāñjalisāram reads:

Your Lord or mine, it does not matter, with a quiet mind, meditate with humility, the Lord, pleased, gives what you seek, and happily will offer more. (śloka 13) ${ }^{2}$

The importance of devotion is also demonstrated in the lives and in the written works of his foremost students, yet it became less of a central point in their own teaching, which primarily focused on āsana or physical practice.

In reference to Krishnamacharya's work, his son Desikachar explains that devotion to God is the ideal way to focus the mind. He adds,

But this devotion to God must not remain just a desire. It must become a regular practice, as this alone, when regularly done, can prevail upon the past tendencies of the mind. The practice involves remembering God in some form, in words, images, rituals, offering flowers or visiting temples,

Stephanie Corigliano is a lecturer at Humboldt State University. She specializes in Comparative Theology and Yoga studies. She has an essay in the (2017) book How to Do Comparative Theology (edited by Klaus von Stoch and Francis X. Clooney), "Theologizing for the Yoga Community? Commitment and Hybridity in Comparative Theology." She is currently working on a monograph that examines the teaching tradition of T. Krishnamacharya and Patañjali's Yogasūtras. 
taking great care that it does not become mechanical... ${ }^{3}$

This highlights the functional role of devotion as a means for focusing the mind. The habit of concentrating on an ideal image can counteract other, less ideal habits. Yet, Desikachar (drawing upon Krishnamacharya) grounds this in a concrete practice that also points to a lived, religious commitment.

Taking seriously both the importance of devotion and the refrain, "Your Lord or mine, it does not matter," this essay turns to look at the phenomena of Christian Yoga as a transnational, devotional approach to Yoga practice. Initially I look at the question, 'What is Yoga?' for proponents of Christian Yoga? How is it practiced and what are its goals? And, what is changed or lost with the use of a more specifically religious approach to Yoga practice? Subsequently, I compare this specifically religious approach to Yoga practice with the non-sectarian approach of Krishnamacharya. In closing, I argue that Christian Yoga, though representative of an entirely distinct movement in its own right, might be viewed as a natural result of the philosophical precepts set forth by 20th century proponents of Yoga like Krishnamacharya.

The continuity between the Yoga tradition of Krishnamacharya and Christian Yoga may appear untenable to proponents of either form of Yoga practice, yet despite their more obvious differences, they both share an emphasis on physical Yoga practice that is combined with devotion to God. In particular, practitioners of Yoga in the tradition of Krishnamacharya may resist the recommendation that Yoga is (ideally) a devotional practice. The turn to Yoga is, for many contemporary practitioners, an explicit turn away from traditional religious communities. Still, as evidenced in the study of Krishnamacharya's work, Yoga without a specific religious commitment is appropriate primarily for those in the beginning stages of practice. Advanced practice means making specific, devotional commitments. On the other hand, I contend that Christian Yoga may find a common ground with contemporary Yoga movements, and a wider acceptance within particular Church settings, by emphasizing the dialectical relationship between technique and religious commitment that is prevalent in many Hindu approaches to Yoga.

This article is a work of comparative theology. Thus, I provide some history and detail for both traditions and consider the ways in which attention to similarities and differences can help practitioners, both Christian and non-Christian, to deepen their experience of Yoga, faith commitment, and community.

\section{Christian Yoga: A Brief Overview}

Christians have a long history of appreciating and appropriating Hindu practices. The earliest examples of this were attempts to evangelize the Hindu by learning Indian languages and texts, even taking on Hindu garb and emulating aspects of Indian culture. ${ }^{4}$ However, particularly since the early 1900's, there has been a more active and reflective engagement of Christians with Hindu spiritual practices. ${ }^{5}$ The result, evidenced in the Christian ashram movement in India and in select communities outside of India, is often termed "Christian Yoga." This spirituality blends aspects of Yoga philosophy and practice with the ideals of Christianity, most distinctly, the belief in Christ and the hope for salvation. 
There are at least three categories that differentiate the broad spectrum of what might be termed "Christian Yoga." The first are those who have combined aspects of Yoga philosophy and practice with Christianity with minimal concern for Christian orthodoxy or tradition and who have instead promoted a new religious community. This includes thinkers like A.K. Mozumdar, an early proponent of New Thought and author of The Life and the Way: Christian Yoga Metaphysics (1911).

The second category emerges from a Hindu religious worldview and includes works like Jesus Christ and Yoga, by Shyam Sundar Goswami, and The Yoga of Jesus, based on talks given by Paramahansa Yoganananda (2007). These texts examine the life and teachings of Christ through the lens of Yoga (and according to the Yogasütras of Patañjali). Thus, neither author is Christian, but rather they each sought to convey the richness of their own traditions and practices of Yoga in Christian terms.

The third category includes Christians who turn to Yoga in order to enrich and expand their own practice of Christian faith. In this latter category, a significant early work is The Use of Yoga in Prayer, by Dewan Bhahdur A.S. Appasamy (1926). His focus, as indicated by the title of his work, is upon the usefulness of Yoga for deepening the experience of prayer. Appasamy defines prayer as "the attempt to realize steadily and continuously the presence of God." ${ }^{6}$ As such, he turns to Yoga as a technique to cultivate concentration or steadiness of mind, ultimately aimed at communion with God.

Appasamy explains that he personally took up Yoga practice because he found it was not possible to find Christian mystics who were actively practicing "communion with God" in India. As a young convert to Christianity he also trained in the Saiva Siddhanta school of Tamil Nadu. This involved a prolonged training in meditation techniques that resulted in several vision experiences. He later studied with a teacher of Advaita Vedanta.

Appasamy argues not only that Christians can and should do Yoga, but that the techniques of Yoga have been integral to Christian contemplative practice all along. In particular, he points to various mystics and parts of the Bible where visions of God are central. ${ }^{7}$ He also goes on to identify prāna (or breath/life-force) with the Holy Spirit such that awareness of the breath in prānāyāma (breath control) or meditation is a practice of bringing awareness to the Holy Spirit. ${ }^{8}$ However, in his experience, practices aimed at a direct realization of God and/or vision of God have been neglected so that Christians now have much that they can learn from Yogic technique. ${ }^{9}$

Departing somewhat from this is the study by B.C.M. Mascarenhas, Yoga and Christian Thought (1973). Mascarenhas' text is presented as a response to what the author identifies as a "nuclear age," or a period in world history that values science over spirituality and is experiencing a decline in world peace as a result. Mascarenhas suggests that one remedy to this predicament is the study of other religions.

Mascarenhas makes a point to disavow popular notions of Yoga (which were common both at the time of his writing and now). In particular, he suggests that Yoga is not "mere" physical effort, ascetic practice, or (necessarily) culturally bound to Hindu practices (i.e. he makes reference to "chanting manthras to weird tunes...") ${ }^{10}$ Rather, he asserts that Yoga is primarily a philosophical system and that it is supplemental other spiritual practices. 
The bulk of Mascarenhas' text presents a study of Hindu texts and practices, saving the final few pages for a comparative discussion. Here he notes that Hindus and Christians share the idea that renunciation and/or restraint is necessary in order to cultivate a deeper level of spirituality or prayer. Ironically, it is here that Mascarenhas makes his primary recommendation to Christians: āsana (physical posture) and prānāyāma (breathing exercises) offer a means to cultivating mindfulness and concentration in ways that are not delineated in Christian texts, although they may be compatible. He insists that āsana and prānnāyāma can be practiced apart from Hindu devotional perspectives and that these physical dimensions can be incorporated into Catholic practice. ${ }^{11}$

A contemporary of Mascarenhas, Jean Michelle Dechanet (1906-1992) takes a distinctly different approach towards Yoga in his books, Christian Yoga $(1956,1973)$ and in Yoga and God: An Invitation to Christian Yoga (1975). Considered by many to be the "Father of Christian Yoga," Dechanet was the first proponent in what has become a larger movement of western Christians who have learned and taught Yoga in the west. Dechanet was a French Catholic priest who suffered from epilepsy as a young man. His personal focus on physical exercise and his initial introduction to Hatha Yoga began as a means to maintain health.

Dechanet's turn to Yoga comes from what he sees as "man's rejection, or rather nonacceptance, of his bodily condition." ${ }^{12}$ Dechanet argues that Christian doctrine has perceived the body as an obstacle to "higher" or more spiritual pursuits. This he describes (more than once) as a process where "people begin by neglecting the body, come to despise it and finish by fleeing it as something dangerous - all in the name of virtue." ${ }^{13}$ Thus, the reason Dechanet teaches Yoga as a Christian is to overcome the unnatural fear of the physical body, which he perceives as a perennial Christian issue.

Unlike the other authors presented here, Dechanet emphasizes an explicitly physical practice of Yoga that includes āsana for the purpose of strengthening and healing the physical body. He acknowledges meditation as the central aspect of Yoga practice, yet suggests that several āsanas and some prānāyāma should be conducted prior to meditation. He then discusses the use of mantras (and suggests that this can be a verse taken intuitively from the Bible) and visualization as practices that will help the individual to learn to sit in silence. Later teachers within this movement like Thomas Ryan, CSP, explicitly combine Christian prayer with specific routines of Yoga āsana and breathing. ${ }^{14}$ In the introduction to his Prayer of Heart \& Body: Meditation and Yoga as Christian Spiritual Practice, Ryan reflects on the irony of the current setting of the bustling Kripalu institute in Western Massachusetts that was sold by the Jesuits in 1985 due to a decrease in novitiates. Ryan notes that Kripalu, like Christian monastics, emphasize celibacy and service, yet it is distinct in its emphasis on the physical body. He states, "Christianity, by contrast, is in the awkward position of trying to affirm the goodness of creation without ever having delighted in human bodiliness." 15

For Dechanet, Yoga is "a technique for individual perfection, an instrument which will help him to become what he is." ${ }^{16}$ Elsewhere he notes, "yoga is a system of practices for the development of human potential." ${ }^{17}$ Like several of the previous authors, he recognizes a difference between spiritual and non-spiritual reasons for doing Yoga. However, he avoids 
framing this in terms of physical vs. meditative practices. Rather, he makes a distinction between Yoga as "an ensemble of techniques," aimed at balance, relaxation, and health and "that whole which is Yoga, which seeks to make the body the instrument of the interior man, and the interior man an enlightened guide for the body." 18

Thomas Ryan, by turn, frames the discussion of Christian meditation and Yoga as part of a "spiritual" and "perennial philosophy," that would be in line with the non-sectarian approaches found in many contemporary schools of Yoga. However, Ryan also notes that the possibility of experiencing God within is fully supported by the Church. He quotes then Joseph Cardinal Ratzinger as stating, "The Fathers are perfectly correct in speaking of the divinization of man who, having been incorporated into Christ, the Son of God by nature, may by his grace share in the divine nature and become a "son in the Son."19 Thus, Ryan draws on Yoga technique and philosophy in order to strengthen his Christian community and his writings are explicitly directed to a Christian audience.

Parallel in many ways to the work of Dechanet is the use of Yoga in the Christian ashram movement. Based largely on the works of Western monks and priests, Henri Le Saux, Jules Monchanin, and Bede Griffiths, the ashram movement began in India in the mid-twentieth century as an effort to combine Benedictine monasticism with Hindu ashram spirituality. One example of the use of Yoga in the ashram movement is the 1995 book by V.F Vineeth (CMI), Yoga of Spirituality: Christian Initiation into Indian Spiritual Traditions. While this text is fairly recent compared to the other works discussed here, it is the aggregate of years of Dr. Vineeth's study and experience and, as such, it is representative of the larger Christian ashram movement.

V.F. Vineeth is a long-standing proponent of Christian inculturation, a practice that looks for local, contextual, and indigenous means of practicing Christian devotion. According to Vineeth, the aim of inculturation is to expose "hitherto unknown or forgotten dimensions of Christ." ${ }^{20}$

In my own (very brief) visit in 2012 to Fr. Vineeth's ashram, Vidya-Vanam, just outside of Bangalore, India, I was able to see the circular outdoor space that they use for sun-salutations and meditation each morning. Thus, I was informed that physical postures are an important part of the daily routine at VidyaVanam. However, Vineeth's text, Yoga of Spirituality, focuses almost entirely on promoting seated meditation and contemplation. He understands Yoga as the transformation of consciousness. At the heart of his text he follows the eight limbs of Patañjali's aștānga yoga to trace the cultivation of spiritual growth and, in his words, "to expose [this as] a genuine Christian experience." ${ }^{21}$

Each of the Christian authors discussed here turns to Yoga for slightly different reasons; however, they generally share a common search for deepening prayer and spirituality. Dechanet stands out from the others with an explicitly assana-based approach to Yoga and his stated desire to heal what he perceives as the Christian fear of the body. Vineeth and the larger Christian ashram movement are also particularly concerned with expressing a Christian faith through Indian cultural modes. While both Mascarenhas and Appasamy point out metaphysical distinctions between Yoga in the Hindu context and Christianity, all of the 
authors generally agree that Yoga techniques can be employed across religious boundaries. They define Yoga as union with God. Mascarenhas discusses Yoga as both a spiritual realization and as a body of techniques used to cultivate spiritual awakening. Dechanet states that Yoga "will help [the individual] to become what he is." And, Vineeth, as just stated, understands Yoga as the transformation of consciousness.

$20^{\text {th }}$ Century Gurus in India: Krishnamacharya and Āsana-Based Yoga

Parallel to (and, indeed, perhaps the catalyst of) the rise of various Christian Yoga movements in the twentieth century is the rise of NeoVedanta and various prominent scholar-Guru figures like Vivekananda, Kuvalayananda, Sivananda, Sri Aurobindo, Yoganananda, Ramakrishna, and several others. These teachers shared a universalist Hindu worldview that valued and accepted the spiritual paths of others, while promoting Hinduism as the sanātana dharma, or the superior most inclusive path of eternal truths. Proponents of this philosophy maintained a general acceptance of truth in other religious traditions (and accepted students from different religious backgrounds) and at the same time they maintained a firm religious commitment to their own Hindu tradition.

A prime example of this balancing act between openness to other traditions and commitment to Hindu practices is Tirumalai Krishnamacharya

(1888-1989). Krishnamacharya taught Yoga for the Maharaja of Mysore at the Yoga shala on the palace grounds from 1933-1955. It was there that he fully developed his unique approach to Yoga $\bar{a}$ sana (or postures) and became renowned as one of the great Yoga masters of his time.

The tradition of Krishnamacharaya presents Yoga (at least in the beginning stages) as a posture-based practice that need not be associated with philosophical or religious history. In this view, the postures themselves constitute a healing practice (following the medical model of Yoga pioneered by Kuvalayananda and discussed in the work of Joseph S. Alter ${ }^{22}$ ) and are promoted as beneficial in and of themselves. This perspective, combined with a lack of the formal aśrama (monastery/retreat) setting, has lead to a more secular appropriation of Yoga practice than many other forms of Yoga that similarly became popular within the twentieth century.

The lack of the aśram setting is likely based on the perspective that Yoga should be a practice for householders, people with families and jobs, and does not require a retreat from the world. In this way, the central ritual for the Yoga practitioners in the various traditions is the practice itself.

Krishnamacharya published his first treatise on Yoga, Yoga Makaranda, in 1934 shortly after he established his school at the Jaganmohan Palace. ${ }^{23}$ This text begins with the question, "Why should I practice yoga?" In response (to his own question), Krishnamacharya enters into a critique of the then current (1934) rise of the "commercial mentality." He writes,

We should never insist on, nor even hope for, immediate results in return for an hour or two repeating mantras or engaging in worship (puja), yoga practice, or dawn and evening prayers, etc. If we do, we are like the coolie who considers that it is not worth doing a couple of hours work if he does not receive his wages. Ever since monetary 
considerations of this kind have caught hold of our minds, we have become victims of the venal mindset and are growing meaner by the day. ${ }^{24}$

Krishnamacharya equates the hope for an immediate result from practice with the exchange of money for service and suggests that this fundamentally denigrates the process of worship/Yoga and subjects it to corruption and mal-intent. Importantly, it is not the exchange of money for service that is subject of critique, but rather the expectation that worship/Yoga will produce immediate results, or that these immediate results would be the reason for practice. In this way, worship/yoga are set apart from other life endeavors.

Despite this plea for patience and the notion of "higher aspirations" the next section of the text goes on to promise that through the practice of Yoga, "the desired benefits of health, strength, happiness, and stability of the mind will be gained..." ${ }^{25}$ In the text this list of benefits is correlated to the increase of sattvaguna, or the guna of sweetness and discernment (as opposed to rajas/fire and tamas/lethargy). In this way, a dialectic between "higher aspirations" and immediate rewards is set forth at the beginning of Krishnamacharya's text. In the work of Krishnamacharya (and in the Yogasūtras) health, strength, happiness, and stability of mind can be seen as foundational accomplishments which are necessary to be able to progress to more sustained levels of concentration (dhärana, dhyāna, samädhi or concentration, meditation, absorption). They also provide a measurable motivation for practice and, for some, may appear as sufficient end goals.

On this point, the long time student and biographer of Krishnamacharya, A. G. Mohan summarizes Krishnamacharya's work in the Yoga Makaranda as stating:

Students of yoga should pay particular attention to the body and mind in the early stages of practice. Problems will not arise if attention is not paid to the atma (self) in the initial stages. As the practitioner progresses, equal emphasis must be laid on the body, mind, and self. ${ }^{26}$

Accordingly, Yoga practice may begin as a purely physiological and psychological training (body and mind). The spiritual or religious component of Yoga (related to the concept of self and salvation or self-realization) becomes relevant at later stages of practice.

Mohan's text further explains, "By health and calmness in the body, there is steadiness and calmness in the mind. By steadiness and calmness of the mind, the blissful experience of the self is revealed." ${ }^{27}$ Thus, according to Mohan's reading of the Yoga Makaranda, in the initial stages of practice, attention to the concept of self is not necessary. Since the physical body is regarded as the catalyst for transformation, this is the focus of practice in the initial stages.

The final sections of the Yoga Makaranka make a special plea to Indian youth that they learn the depth of their own heritage. Even stating, "If we remain quiet, the foreigners will become our yoga gurus!" ${ }^{28}$ In this we see a strong support for the trajectory outlined by Mark Singleton that the development of modern āsana practice was influenced by the rising popularity of physical culture and was set forth as a "native" practice that could support the cause of Indian nationalism. ${ }^{29}$ Like Gandhi's rejection of European-made fabric in favor of Indian homespun khadi, the suggestion here is that in Yoga, India could find an indigenous 
means of cultivating strength and health. This point is especially interesting for the current study, since despite an emphasis on the general, non-religious benefits of Yoga, it is clear that Krishnamacharya also intended his approach to Yoga to appeal to young Indians and to support indigenous, Hindu pride. ${ }^{30}$ Thus, he used a broad, widely accepting, approach to Yoga on the world stage, in part, as a means to strengthen particular religious devotion at home.

Another text by Krishnamacharya, The Yoga Rahasya, ${ }^{31}$ was originally attributed to the sage Nāthamuni and said to have been transmitted through Krishnamacharya. In this text Krishnamacharya frames the interpretation of the Yogasūtra as a text of bhakti Yoga, that of devotion (this is also the primary means and focus for Yoga in the context of the Bhagavad Gitā). ${ }^{32}$ Śloka 1.5 of Yoga Rahasya then reads,

bhukti mukti phale tatra yoganuștānato /

bhavato bhagavadbhakto muktyartham bhajate harim //

anyastu bhuktimātre tu na tat śāstreșu sammatam//

The fruits of yoga practice (whether Bhakti or Prapatti yoga) can be material (bhukti) or freedom from suffering (mukti). Those who are devotees of the Lord, praise Hari for the purpose of mukti. Others seek material benefit, which is not approved of by the Śāstra-s. ${ }^{33}$

Yoga Rahasya 1.10 then explains devotional Yoga practice, "Bound by actions and their consequences, men do not realize the Lord. Thus, resolving to please Him, one must continuously practice yoga..." This is followed up with YR 1.13, "During the practice of the ang $\bar{a}-s$ of yoga, one must constantly remember Harī, have discipline in speech and control over the senses and must follow his dharma." ${ }^{34}$ As such, this particular treatise on Yoga is distinct from the majority of Krishnamacharya's work in that it unapologetically advocates for a particular theological perspective and establishes a clear ontology for further claims made in relation to the practice of Yoga. God is Vishnu-Narayana; devotion is described as the action of remembering Harī. ${ }^{35}$ The text acknowledges that Yoga can be done for material benefits, but reminds the reader that (especially for Hindu devotees) it is better to aspire for liberation.

The importance of a theistic/devotional stance is also prominent in the later philosophical work and prose of Krishnamacharya (discussed in the introduction), yet here it is more clearly set forth as part of a non-sectarian approach to practice. He announces, "Your Lord or mine, it does not matter." Yet, this is combined with the charge that "devotion to God must not remain just a desire. It must become a regular practice..." that involves ritual and the naming of a particular form of God.

\section{Christian Yoga and Modern Yoga in Dialogue}

Taking seriously both the importance of devotion in the teaching tradition of Krishnamacharya and the refrain, "Your Lord or mine, it does not matter," practitioners of this Yoga are faced with a unique challenge that values equally religious tradition and religious pluralism. In many ways, the Christian use of Yoga in prayer and as a means for centering devotion (especially in the work of Dechanet) is in line with Krishnamacharya's insistence on the importance of devotion for success in Yoga. In this way, both proponents of Christian Yoga and modern practitioners who seek to align their understanding of Yoga with the lineage of 
Krishnamacharya ultimately require some kind of explicit sectarian commitment to God.

However, for Krishnamacharya the specific nature of this commitment is balanced with a radical openness to other religious traditions in which he neither promotes his own sectarian beliefs nor attempts to learn from the other. In this way he protects the specific nature of his own religious commitments while simultaneously promoting a universal approach to spirituality and Yoga. Yoga in the tradition of Krishnamacharya is learned initially through āsana and prānāyāma and, for some, it also includes philosophical discussion and the study of texts. However, the heart of Yoga practice in this context is a religiously neutral space, open to believers from different traditions. The obvious benefit of this approach is accessibility and the possibility of creating vibrant communities of spiritual practice that cross religious traditions.

On the other hand, the lack of engagement with religious particulars makes the question of how to practice devotion with (or along side) Yoga ambiguous, especially for a non-Hindu, transnational audience. For the most part, students share in a communal experience of Yoga, but are left to express devotion on their own or in a separate community of religious affiliation. In the end, by not engaging the specificity of religious praxis in relation to Yoga, this potentially important component of practice is bypassed by many contemporary practitioners. Thus, Yoga becomes increasingly secular and, if we take seriously the emphasis given to devotion in the written work of Krishnamacharya, perhaps, the full potential of practice is not realized.

The overview of Christian Yoga demonstrated the varied and persistent interest in Yoga by Christians. Of all the Christian Yoga proponents, Dechanet comes closest to teaching Yoga in ways similar to the written tradition of Krishnamacharya. However, those that look to Dechanet as the "Father of Christian Yoga," make explicit effort to combine Christian prayer and imagery at each stage of Yoga practice. Thus, while these proponents of Christian Yoga maintain that Yoga technique is different from Christian faith, the specificity of the particular practice they promote is open primarily to Christians. From a practical standpoint, this may limit the size (and therefore the accessibility) of a given community and, in turn, this can lead to lack of depth and training for teachers of that community (mainly because there would be fewer teachers). It also entails a very specific form of Yoga practice that is based more in Christian spirituality than in Yoga technique. of course, Ryan is explicitly concerned with linking Christian doctrine and prayer to Yoga for the benefit of his Christian community. However, I wonder if an approach that initially emphasized the more physical, universal, and spiritual benefits of practice would have a greater appeal for a younger audience?

Interestingly, proponents of the Hindu sanatana dharma, or the path of eternal truths, like Krishnamacharya, promoted the most universal aspects of their religious and spiritual tradition. Through the separation made between practical technique and religious particularities, they appealed to large numbers of non-Hindus. However, their goal was not to evangelize the other (indeed, many Hindus contend that conversion is impossible or irrelevant); rather, they sought to reignite pride and enthusiasm for Hindu devotional life for those who were already Hindu by birth, but who may have fallen away from an active religious 
life. Thus, inclusion of "the other" in this context strengthened Hindu religious communities by demonstrating the value and appeal of Yoga techniques on a world stage and, perhaps, simply by encouraging larger communities of practice. The teaching tradition of Krishnamacharya generally emphasizes the "transformation of the physical body" as a nonsectarian, spiritual awakening. As such, the "secular" practice of Yoga could equally benefit Christians, especially if there is a community and/or teachers available who are grounded in both the Christian tradition and Yoga techniques. In addition, sustained interreligious dialogue in the context of particular Yoga communities may benefit both proponents of Christian Yoga and those in the tradition of Krishnamacharya.

The distinction between sectarian commitments and technique, evidenced in the work of Krishnamacharya, emphasizes the benefits of practice for a variety of reasons and, in this way, it potentially opens the door to dialogue, interreligious practice, and transnational community. Yet, mere tolerance

\section{Notes}

${ }^{1}$ Edwin Bryant, The Yoga Sūtras of Patañjali: A New Edition, Translation, and Commentary. New York: North Point Press (2009: 49).

${ }^{2} \mathrm{~T}$ Krishnamacharya, Yogāãjalisāram. TKV Desikachar (trans). Chennai: Krishnamacharya Yoga Mandiram (1995, 2001: 27).

${ }^{3}$ TKV Desikachar, The Yoga of T. Krishnamacharya. Madras, India: Krishnamacharya Yoga Mandiram (1982: 47).

${ }^{4}$ For example, see the history and work of Roberto de Nobili (1577-1656).

${ }^{5}$ See the work of Brahmabandhab Upadhyay (1861-1907), Pierre Johanns, S.J. (1882-1955), Henri Le of the other is not dialogue and does little to deepen a communal understanding of devotion. In the end, Krishnamacharya's charge that "devotion to God must not remain just a desire" and that it must also become a regular practice (with name and ritual) raises an important issue for contemporary practitioners. It also points to something like Christian Yoga (at least for nonHindu and/or Christian practitioners), with its philosophical and doctrinal commitments.

Christian Yoga is devotional Yoga, yet it combines the techniques of Yoga with Christian philosophy even in the initial stages of practice. Krishnamacharya suggested beginning with a physical practice and emphasized the practice of devotion with Yoga as an advanced, and even optional, technique. Krishnamacharya's approach has also succeeded in fostering international and interreligious communities of Yoga practitioners. In and of itself, this is a powerful fact. However, in order to practice devotion in an interreligious community, that community must also be willing to engage with religious diversity and the particulars of religious belief and ritual.

Saux (1910-1973), Jules Monchanin (1895-1957), and others.

${ }^{6}$ Dewan Bhahdur A.S. Appasamy: The Use of Yoga in Prayer. Madras, India: The Christian Literature Society for India (1926: 1).

${ }^{7}$ Appasamy (1926: 11; 24).

${ }^{8}$ Appasamy (1926: 19).

9 The suspicion of Pelagianism, or salvation through works may arise here for some readers. Appasamy defends his own work from this charge by explaining that not all Christians will see visions and that, "The gifts of the Spirit are diverse and men are summoned by God to minister in His Kingdom in diverse ways." He goes on to argue that the ability to 
"see God" is the "heritage of all Christians." (1926: 28).

10 B.C.M. Mascarenhas, Yoga and Christian Thought. Bombay, India: Saint Paul Publications (1973:2).

${ }^{11}$ B.C.M. Mascarenhas, (1973:88).

${ }^{12}$ J.-M. Dechanet, Yoga and God: An Invitation to Christian Yoga. Indiana: Abbey Press (1975: preface).

${ }^{13}$ Dechanet, (1975: 19).

${ }^{14}$ See, for example, Thomas Ryan's Prayer of Heart \& Body: Meditation and Yoga as Christian Spiritual Practice (1995); Reclaiming the Body in Christian Spirituality (2005); and the DVD, Yoga Prayer: An Embodied Christian Spiritual Practice (2004; 2005).

${ }^{15}$ He goes on to state, "One would think that between our two central doctrines of the Incarnation and the Resurrection - the one, in which God chose to call human bodiliness "home," and the other, in which that broken, weary body is not discarded but re-embraced and taken into the very life of the Trinity for all eternity - we could do better at helping people to embrace and relate positively to their enspirited flesh as a joyful mode of existence!" Ryan, (1995: 7).

${ }^{16}$ Dechanet, (1975: 17), original emphasis.

17 See: http://www.christianspracticing yoga.com/is-yoga-a-religion/ (accessed on 11/8/2016).

${ }^{18}$ Dechanet (1975: 17-18).

${ }^{19}$ Joseph Cardinal Ratzinger, "Letter to the bishops of the Catholic Chruch on some aspects of Christian Meditation," in L'Osservatore Famano, 2 January 1990, p. 9 in Ryan, (1995: 27). It is also interesting that Thomas Ryan specifically references and quotes from this document, since it otherwise explicitly warns against the use of eastern form of practice like Yoga and meditation. By engaging with this text Ryan is making a strong effort to show ways that Yoga and meditation can be beneficial to the faithful Catholic.

20 V.F Vineeth's (CMI), Yoga of Spirituality: Christian Initiation into Indian Spiritual Traditions. Bangalore, India: Vidya Vanam Publications (1995: 14).
${ }^{21}$ Vineeth, (1995: 1).

${ }^{22}$ In Yoga in Modern India: The Body Between Science and Philosophy. Princeton: Princeton University Press (2004), Joseph S. Alter explains how the early efforts of Hindu nationalism, aimed at recovering strength and dignity for Hindu-Indians as well as directed towards Indian independence from Britain, also reclaimed particular aspects of Hindu culture, like Yoga, that had previously been disparaged in the European imagination. Alter focuses specifically on the work of Swami Kuvalayananda (1883-1966) and his effort to bridge esoteric Yogic practices with scientific analysis (82-83).

23 "Yoga Makaranda of T. Krishnamacharya," Mark Singleton, M. Narasimhan and M.A. Jayashree (trans. and eds.) in Yoga in Practice, David White (ed.) Princeton: Princeton University Press (2012). Additional English translations of this text (from a previously translated Tamil edition) are available from TKV and Kaustub Desikachar, Yoga Makaranda: The Nectar of Yoga, T. Krishnamacharya, edited and translated by TKV Desikachar. Chennai, India: Media Garuda (2011). A synopsis of the text is also found in A.G. Mohan biography of Krishnamacharya (2010). Mohan was a long-term student of Krishnamacharya's towards the later part of his life. Thus he brings a particularly personal, practicebased insight to his biographical accounts and to his reading of Krishnamcharya's texts.

${ }^{24}$ Singleton (2012: 344).

${ }^{25}$ Singleton (2012: 344$)$.

${ }^{26}$ Mohan (2010: 143) (my emphasis).

${ }^{27}$ Mohan (2010: 144).

${ }^{28}$ Mohan (2010: 144).

${ }^{29}$ Singleton (2008). Chapter 4, especially (91-94) discusses the international influence of the YMCA (circa 1930) in reimagining the role of physical fitness within the formation of whole person. Following India's national director of the YMCA, J.H. Gray, Singleton writes, "Physical culture, as conceived by the Indian YMCA, was education through the body, not of the body." (original emphasis) (91). In the next chapter Singleton quotes Vivekananda as stating, “...unless one has a good physique one can never 
aspire to Self-realization." (101) Singleton then goes on to suggest that an understanding of Yoga as physical training became an alibi for training towards violent anti-colonial resistance. (103) In this, strength and endurance training were complemented by a nationalistic rhetoric that touted the superiority of indigenous Indian practices. Additionally, this militaristic focus also may have contributed to the particular developments of assana (and its ascendancy to the primary or best-known component of Yoga practice) and to the introduction of new forms of äsana postures. Singleton's work is effective in drawing out the particular development of Yoga in India during the twentieth century. Clearly, this shared context would have influenced the development of Krishnamacharya's thought. However, Singleton's work also overlooks historical background (c.f. medieval hațha texts as well as historical commentators of the YS that place emphasis on health and purity of the body) that may counterbalance the impression that Yoga for householders (non-monks/renunciates) for the initial purpose of health is an exclusive development of the twentieth century.

${ }^{30}$ In the introduction to the Krishnamacharya Healing \& Yoga Foundation's translation of the Yoga Makaranda, Krishnamacharya's grandson, Kausthub Desikachar, highlights this point stating, "While Krishnamacharya never involved himself in politics or political movements, it is quite clear from his words in this book, that he was a nationalist at heart..." (K. Desikachar in Yoga Makaranda, 2011:21).

${ }^{31}$ The first publication of this text is 1998 , nine years after Krishnamacharya's death. However, based on talks and other texts that reference this composition, it was likely recorded shortly after Yoga Makaranka (1937/1938).

${ }^{32}$ A.G. Mohan, (135-6). Mohan maintains that this approach of reading the YS from the specific viewpoint of Vishishta-advaita was taken up by Krishnamacharya in order to offer a counter perspective to the several interpretations that were in circulation from schools of Śankara's Advaitavedānta. However, in this, Mohan also contends that the practical components of practice are the same and that only the philosophical perspective (namely the sūtras which directly refer to iśvara, or God) are influenced by this interpretation. See also the short video on this topic: http://www.youtube.com/ watch?v=rKucJJppmMo

This general approach, which demonstrates the variety of interpretations and also underscores a certain continuity within the text irregardless of the philosophical perspective also underscores the averred theological neutrality of Yoga practice in the tradition of the YS, which is promoted by Krishnamacharya and also by all three of the MY gurus discussed in this text.

${ }^{33}$ Quotations from the Yoga Rahasya are taken from TKV Desikachar's translation, Nāthamuni's Yoga Rahasya: Presented by T. Krishnamacharya. Chennai: Krishnamacharya Yoga Mandiram $(1998,2010)$. This is primarily a translation of the text with a few brief notes of commentary inserted by Krishnamacharya, presumably added after the composition of the original text.

${ }^{34}$ Krishnamacharya $(1998,2010: 25)$.

${ }^{35}$ As stated above, İśvara (God) is identified as Vishnu-Narayana (Harī) most likely on account of Krishnamacharya's own religious background. 